الجمعية المصرية للقر اعة و المعرفة عضو الجمعية الدولية للمعرفة المي

\title{
Developing Students' Critical Reading Skills through GDS
}

\section{By}

Rania Mokhtar Abdullah Dorra

Prof. Eman El-bashbishy, Dr. Moataza Dadour

Professor of ELT, Lecturer of ELT,

Mansoura University Damietta University 


\section{ABSTRACT}

This study aimed at investigating the effectiveness of teaching grammar using (GDS) guided discovery strategy in developing some critical reading skills among second-year preparatory school students. A random sample of 82 students was chosen of the academic year 2014-2015 in Damietta Governorate from Al-Roda Prep School for girls. The students were randomly distributed into two groups; the experimental group which comprised 42 students and the control group which comprised 40 students. A critical reading skills questionnaire was prepared by the researcher to identify the most important skills necessary for the second year prep school students. A critical reading test was designed by the researcher to be used as a test to assess students' progress in critical reading skills. The experiment was implemented in the second term of the academic year 2014-2015. It has lasted for 8 weeks including two sessions for the pre and post tests. The experimental group was taught using guided discovery strategy. On the other hand, students of the control group were taught the same content using the regular way. The data obtained from the study has been analyzed statistically by SPSS program. Research results revealed significant differences between the post-test mean scores of the experimental and control groups in the critical reading skills in favor of the experimental group. It was concluded that the present study provided evidence for the effectiveness of guided discovery strategy in developing students' critical reading skills among second year preparatory school students. 


\section{Introduction}

English language has become the overwhelming language in the world as a result of the scientific and technological revolution. To keep up with this progress, learners have to read and understand what is read. Reading is one of language skills that researchers, according to Nia (2011), realize that it is not a passive skill as the reader has a very active role in the comprehension of the presented materials.

However; Hassan (2013) confirmed that the conventional methods followed in teaching reading are of limited value in producing proficient readers. Learners are only recipients of knowledge. Moreover, the absence of an integrated syllabus for reading courses renders them excursive and disconnected, and not fully exploited to raise the students' reading abilities and skills in order to master the English language.

Block (2001) and Zwiers (2004) illustrate that comprehending a text at the advanced levels is critical reading which entails reading to question, to make connections, detect bias, and in short to transfer critical thinking habits into the process of comprehending texts. Thus, readers can enhance their comprehension by employing their skills to analyze, synthesize, and evaluate the written text.

For Wallace (2003) one goal of critical reading pedagogy is to make the readers be aware of the hidden elements of the language.

Geith (2007) asserted that the integrative thinking and language skills occur in a much more comprehensive world than a mere mechanical process of language learning. This 
demands different visions produced by curriculum designers, teachers, and learners who should be able to predict future characteristics according to their own visions.

\section{Statement of the Problem:}

Based on the above, developing critical reading skills is a necessity that helps in developing learners' mental abilities. These skills will enable learners to analyze, infer and evaluate any kind of data or information.

However, when surveying the previous studies, the researcher concluded that the previous studies did not investigate how to develop critical reading skills among the preparatory stage learners. Based on, there is a need to employ a strategy that promotes integration between language skills and components to develop the target skills.

\section{Research Questions:}

This study was an attempt to answer the following major question:

What is the effectiveness of teaching grammar via guided discovery strategy on developing the second year prep students' critical reading skills?

The main question can be clarified through stating the following sub- questions:

- What are the critical reading skills intended to be developed for the second year prep pupils?

- To what extent do second year prep students' possess critical reading skills?

- What is the effectiveness of using guided discovery strategy on developing second year prep students' critical reading skills? 


\section{الجمعية المصرية للقراءة والمعرفة عضو الجمعية الدولية للمعرفة المئ}

\section{Purposes of the Study:}

\section{This study aimed at achieving the following purposes:}

- Identifying the most important critical reading skills required for the second year prep students.

- Exploring how effective guided discovery strategy is on developing critical reading skills.

\section{Research Hypotheses:}

Three hypotheses were formulated to be tested as follows:

- There are statistically significant differences at $(\alpha \leq$ $0.05)$ in the mean scores of each level of critical reading skills in the pre and post- test of the experimental group.

- There are statistically significant differences at $(\alpha \leq$ $0.05)$ in the mean scores of each level of critical reading skills in the post-test between the experimental group and the control group.

\section{Significance of the Study:}

- It may improve learners' critical reading skills.

- It may help teachers to adopt the innovative strategies to help in solving some problems in teaching English.

- Finally, it may encourage other researchers to conduct further studies on the same topic to enrich the local literature.

\section{Limitations of the Study}

1. The dependent variable was limited to three levels of critical reading. Each level involved some sub-skills: Analysis level involved, Extract the prevalent linguistic mistakes, Pronoun reference, Differentiate between helping verbs and main verbs, Identify the tense of the context. Inferential level involved: Cause effect relationship, Proper tense usage, Proper pronoun usage, Recognize what punctuation suggests. Evaluation level 
involved Evaluate shifts in verb tense, Evaluate Subjectverb agreement.

2. The independent variable was limited to teaching grammar using guided discovery strategy.

3. Time limitation for this study was seven weeks.

4. This study was implemented in Damietta Governorate. The sample of the study was chosen randomly to be as experimental group and the other as control one

\section{Definition of the Terms:}

\section{A. Guided discovery:}

UCLES (2011) defines it as "A way of teaching in which a teacher provides examples of the target language and then guides the learners to workout the language rules for themselves".

The researcher states the following operational definitions:

Guided Discovery is an instructional strategy based on leading questions and problem framing that guides learners to discover relations and concepts by getting involved in the classroom interaction where the teacher helps them to be more active and more responsible for their learning.

\section{B. Critical reading:}

Palinscar and david ( 1991) states that critical reading is the ability to clarify purpose, make use of relevant background knowledge ,focus on major content, critically evaluate content, draw and test inferences and monitor comprehension.

The researcher states the following operational definition:

Critical reading is Learner's ability to analyze, infer and evaluate the quality, accuracy and the indication of the grammatical rules that is used in a text.

\section{Literature Review: \\ Critical reading:}


Reading is one of the most important skills, if not the most, among language skills. Reading affects all aspects of people's life especially academic achievement. The purpose of reading process is not only focus on memorizing patterns and practicing fluency. However; it is a visual and cognitive process to extract meaning, processing information, and relating it to existing experience (Millrood, 2001). Critical reading, which is one of the high levels of reading comprehension, is a necessary activity that should be practiced by readers to enable them to understand the message to analyze and to evaluate the component (Esleem, 2012).

Wallace (2003) introduced an approach to the teaching of critical reading based on Hallidyan functional grammar which "offers certain advantages over other models in that it moves from general to even more specific features, allowing students of varying linguistic sophistication accessible entry points to the grammar." According to Wallace the knowledge of the grammar of written language constitutes a resource not only to analyze texts but, as Halliday points out (1994), is 'a critical resource for asking questions about (texts): why is the grammar organized as it is? Why has written language evolved in this way?'

Also she states that one of critical reading contributions to foreign language learners is that their participating in the critical talk around the texts first requires precision which may enhance grammatical accuracy and general fluency. Consequently, a lot of studies have been conducted to combine grammar and reading.

Guo(2006) states that reading ability is determined by many factors of language skills. One of these components is syntactic awareness which plays a very important role in 
reading process from two angles; first, it could help learners to acquire the essential skills of phonological recording, Secondly, it could enable readers to monitor their comprehension process more effectively.

In this respect, Widodo (2004) adds grammar is thought to furnish the basis for a set of language skills. Regarding to reading, grammar enables learners to comprehend sentence interrelationship in a paragraph, a passage and a text.

The presence of a relationship between grammar and reading comprehension has been will indicated. In their study, Deher and Zeng (1990) interviewed 98 randomly selected first graders. Sixty five of those children had completed testing records and remained in the school system through grade 5. The findings indicated that syntactic awareness was statistically significant predictor of students' reading comprehension performance in both third and fifth grades.

Building on; developing reading skills should be approached from a holistic perspective, (Frances, 1994), in parallel with fostering grammatical development in the classroom.

\section{Guided Discovery Strategy (GDS):}

Saumell (2012) points out that GDS is aligned with more modern language learning theories that advocate student participation and the development of critical thinking skills and autonomy. It relates to analytic learning and problem solving. It helps learners engage in the learning process and thus make personal connections that anchor their learning. It is a learner-centered approach that increases participation and fosters collaboration. It empowers learners towards assuming responsibility for their own learning and becoming more autonomous. It is therefore a valid and useful 
way of approaching language instruction at all levels of language ability.

Tennant (2011) clarifies that guided discovery is an implicit approach to grammar where the students are 'led' to the grammar through a series of steps. In other words, the guided discovery aims to lead students towards a generalized grammar rule or pattern.

Abdel Fatah's (1992) study was designed to examine the effect of the discovery method on third year's preparatory school Al-Azhar students' achievement in grammar. The subjects of the study were 112 male and female students. They were divided into two groups: each group consisted of control and experimental students. The lessons were taught through reconstructing the grammar syllabus in a way that is applicable to the use of the discovery method. An achievement test in grammar prepared by the researcher was administered to the two groups. The results indicate that the discovery method was very effective in developing females' achievement of grammar.

In the same context, Sabry's (2004) study revealed the effect of guided discovery method on developing secondary stage students' achievement in Arabic grammar in comparison with the traditional method. Results indicated that students' cognitive levels and grammatical concepts were developed. These findings are similar to Al-Saify (2012) who developed some Arabic grammatical rules for primary school pupils using a multimedia program based on guided discovery. The findings indicated that guided discovery enhances self learning, autonomy and self-reliance.

\section{Method:}

\section{Design of the Study:}


The present study adopted the quasi-experimental design, employing a pre-post two groups (experimental and control group) design.

\section{Participants:}

The participants in this study were 82 students. They were randomly selected from the second year preparatory students at Al-Roda prep school for girls. Two classes were randomly chosen; one experimental and the other control. The experimental group was of 42 students and the control group was of 40students. They have been studying English for eight years. Participating students' age in the two groups ranged from fourteen to fifteen years old. Thus, the students constituted a homogeneous group in terms of their background and proficiency. The study was carried out during the second term of the academic year 2014-2015.

\section{Instrument:}

A) A critical reading skills checklist (prepared by the researcher) to identify the most important skills necessary for the second year preparatory school students.

B) A pre-post critical reading test (prepared by the researcher) administered to all participants of the sample before and after the experiment.

\section{Procedure:}

- Reviewing the literature and related studies.

- Designing the study tools and preparing them for application.

- Administering the critical reading pre-test to the whole sample of the study.

- Implementing the experiment according to the teacher's guide for the experimental group while the control one was taught by the ordinary method.

- Administering the post test to the two groups (each in a separate section). 
- Analyzing the results obtained from the pre-posttest administering using suitable statistical techniques.

- Discussion of the study results.

- Giving suggestions and recommendations for further research.

\section{Data Analysis and Results:}

The t-test for independent samples was used to compare between the post-test mean scores of the two groups. For estimating the reliability test, the researcher used the test/retest method.

The results in table (1) show that the mean scores for the experimental group at analysis level is (4.57) and the standard deviation is (1.40), also, the mean scores for the control group is (4.30) and the standard deviation is (1.52). $\mathrm{T}$ - Value is (0.48) which indicates that there was no significant difference at $(0.40)$ level between the two groups which are equivalent at the three levels of critical reading. So, the first hypothesis was accepted.

Table (1): T- test Differences between the pre and post test

for the Experimental Group

\begin{tabular}{|c|c|c|c|c|c|c|}
\hline $\begin{array}{c}\text { Achievement test } \\
\text { levels }\end{array}$ & & $\mathbf{N}$ & Mean & SD & $\begin{array}{l}\text { T-test } \\
\text { value }\end{array}$ & $\begin{array}{c}\text { Significan } \\
\text { ce level }\end{array}$ \\
\hline \multirow{2}{*}{ Analysis } & Post test & 42 & 7.10 & 1.49 & \multirow{2}{*}{11.26} & \multirow{2}{*}{0.001} \\
\hline & Pre-test & 42 & 4.57 & 1.40 & & \\
\hline \multirow{2}{*}{ Inference } & Post test & 42 & 10.02 & 2.21 & \multirow{2}{*}{15.48} & \multirow{2}{*}{0.001} \\
\hline & Pre-test & 42 & 5.57 & 2.12 & & \\
\hline \multirow{2}{*}{ Evaluation } & Post test & 42 & 6.29 & 1.49 & \multirow{2}{*}{16.34} & \multirow{2}{*}{0.001} \\
\hline & Pre-test & 42 & 2.55 & 1.90 & & \\
\hline \multirow{2}{*}{ Achievement test } & Posttest & 42 & 23.40 & 4.24 & \multirow{2}{*}{27.23} & \multirow{2}{*}{0.001} \\
\hline & Pre-test & 42 & 12.69 & 4.99 & & \\
\hline
\end{tabular}

As shown in table (1), the whole test mean score of the posttest (23.40) is higher than that of the pretest (12.69). Tvalue is (27.23), which is significant at 0.01 . Therefore, it is 
clear that the over all critical reading skills were developed after the application of the strategy hence, it was effective. So, the first hypothesis was accepted.

Table (3): T- test Differences between the Experimental and the Control Groups in the Post-Test

\begin{tabular}{|c|c|c|c|c|c|c|}
\hline $\begin{array}{l}\text { Achievement } \\
\text { test levels }\end{array}$ & & $\mathbf{N}$ & Mean & SD & $\begin{array}{l}\text { T-test } \\
\text { value }\end{array}$ & $\begin{array}{l}\text { Significanc } \\
\text { e level }\end{array}$ \\
\hline \multirow{2}{*}{ Analysis } & $\begin{array}{l}\text { Experimental } \\
\text { group }\end{array}$ & 42 & 7.10 & 1.49 & \multirow{2}{*}{5.35} & \multirow[t]{2}{*}{0.001} \\
\hline & Control group & 40 & 4.95 & 2.10 & & \\
\hline \multirow[t]{2}{*}{ Inference } & $\begin{array}{l}\text { Experimental } \\
\text { group }\end{array}$ & 42 & 10.02 & 2.21 & \multirow[t]{2}{*}{4.86} & \multirow[t]{2}{*}{0.001} \\
\hline & Control group & 40 & 7.38 & 2.71 & & \\
\hline \multirow[t]{2}{*}{ Evaluation } & $\begin{array}{l}\text { Experimental } \\
\text { group }\end{array}$ & 42 & 6.29 & 1.49 & \multirow[t]{2}{*}{5.07} & \multirow[t]{2}{*}{0.001} \\
\hline & Control group & 40 & 4.03 & 2.45 & & \\
\hline \multirow{2}{*}{$\begin{array}{l}\text { Achievemen } \\
\text { t test }\end{array}$} & $\begin{array}{l}\text { Experimental } \\
\text { group }\end{array}$ & 42 & 23.40 & 4.24 & \multirow[t]{2}{*}{6.33} & \multirow[t]{2}{*}{0.001} \\
\hline & Control group & 40 & 16.35 & 5.76 & & \\
\hline
\end{tabular}

To examine the second hypothesis, mean scores of both groups' results on the post-test were computed. T-test Independent Samples was used to measure if there are significant differences between the control group and the experimental one in the mean scores of the post test. The results in table (2) indicate that there are statistically significant differences at (á . 0.05) in the mean scores of each level of critical reading skills in the post-test between the experimental group and the control group in favor of the experimental group, so this hypothesis is accepted.

\section{Discussion:}

The results showed that there were significant differences between the mean scores of the experimental and control groups students in post test favoring the experimental group students. Meanwhile, the results of the in-depth analysis of students' scores on the three levels of critical 
reading also showed that all skills have significantly improved

This means that the experimental group which was taught grammar using guided discovery strategy significantly outperformed the control group taught using the traditional method. The effectiveness of the guided discovery strategy is attributed to various factors as follows:

The cooperative social environment created by the teacher and asking the students to work in pairs and groups increased their participation and fostered collaboration. This result is in accordance with Shoeib's 2015 findings that indicate the importance of cooperative learning in creating a positive atmosphere in the classroom. It allowed students to practice the reading in their groups with coaching from teacher as needed.

In addition, the impact may be due to the well organized stages of the lessons where each stage leads to another. It may be a result of the clear instructions and guidance of the teacher. This result was supported by what Amins'(2006) states about the benefits of guided discovery which indicated the necessity of implementing guided discovery and cooperative learning approaches in teaching reading literature texts conducted by the teacher in the classroom by providing examples and designing educational situations and questions which lead students to deduce certain planned thoughts and new information.

Likewise, the rapid feedback enables monitoring the guidance process to quickly improve any misconception. This also, led the students to think logically and decrease their random answers and increase their self confidence. This result is in accordance with Amin (2008) who confirms the importance of the feedback as a main step during guidance 
process to monitor students learning to avoid misconceptions.

Moreover, following specific steps during presenting the lessons, as a very important feature of guided discovery strategy, made them follow the logical order and decrease their under focused attention, distractibility, and premature decision making. They became more reflective who delay decision making and concentrate so long on bits of information to analyze and evaluate. El Kahlout (2010) and Esleem (2012) study results agreed with the current study in confirming the effectiveness of innovative approaches versus ordinary learning on

\section{Conclusion:}

It has become quite clear from the above results and discussion, that using innovative strategies and creating a cooperative atmosphere inside our classrooms enhances learners' cooperation and fosters them to share and be active during learning process. Thus, one can say that using guided discovery in this study was effective in developing students' critical reading skills.

\section{References}

Abdel-Fatah, A, (1992). The effect of discovery method on third year preparatory school Al-Azhar students' achievement in grammar. Research in Education and Psychology, 5(4), 36.

Amin, R. A. (2008). The effectiveness of the guided discovery method with pictures on developing the EFL writing skills among the fifth year primary school students. Unpublished master thesis. Cairo Institution for Pedagogical Studies. Egypt. 
Block,C.C.(2001) Improving thinking abilities through reading instruction. In a.L Costa $(\mathrm{Ed})$. Developing minds : a resource book for teaching thinking (3rd ed., pp. 292-297). Alexandria, VA: Association for supervision and Curriculum development.

Deher, M. J\& Zenge, S.D. (1990). Using metalinguistic awareness in frist grade to predict reading achievement in third and fifth grades Journal of Educational Research, 84, 13-22

El-Kahlout,A.Y.(2010). The Effectiveness of Using Guided Discovery on Developing Reading Comprehension Skills for the Eleventh Graders in Gaza Governorates.( Master dissertation, Al- Azhar University. Gaza.

Esleem, M,H. (2012).The Effectiveness of Using Story Grammar on Developing Critical Reading Skills for the Ninth Graders at UNRWA Schools - Gaza Governorates Master dissertation, Al- Azhar University, Gaza

Geith ,A. (2007, May). Developing critical thinking for children through EFL learning: Concordia, The Spirit of Inquiry: Developing Critical Thinking, Creativity and Community, Ain Shams University, Cairo, Egypt

Halliday, M. A. (1994). An introduction to funetional grammar. London: Edward AmoId.

Hassan, H. M. (2013). The effectiveness of audio- assisted reading strategy on enhancing EFL Prep students' listening and reading comprehension. Master 
Thesis. Faculty of Education. Mansoura University. Egypt.

Millrood, R. (2001). Teacher development series: Modular course in English teaching methodology.

Nia, M. R. (2011,Dec.). Effects of intensive reading on the mastery of Grammar in Iranian junior high school students The Iranian EFL Journal Volume 7 Issue 6. $145-158$.

Palincsar, A., \& David, Y. (1991). Promoting literacy through classroom dialogue. In E. Hiebert (Ed.), Literacy for a diverse society: Perspectives, practices, and policies, pp. 122-140. NY: Teachers College Press.

Saumell, V. (2012, March). Guided Discovery for Language Instruction: A Framework for Implementation at all Levels.

Shoeib, M.(2015). Developing Reading Comprehension Skills and Summary Writing of the Secondary Stage Students Using a Problem Based Learning Strategy. Master dissertation, Kafr El-Sheikh Universty. Egypt.

Tennant, A.(2011). teaching grammar using the discovery technique.Available at http://www.onestopenglish. com/grammar /grammar-teaching/the-discoverytechnique/

UCLES . (2011) .Teaching Knowledge Test Glossary. University of Cambridge ESOL Examinations . 
Widodo, H. (2004). English students' ability in analyzing the English sentences. Fenomena, 3(2), 27-38.

Guo, Y. (2006). The Relationship among Vocabulary Knowledge, Syntactic Awareness And Reading Comprehension. Master thesis. Florida State University

Zwiers, J. (2004). Building reading comprehension in grade 6-12: a toolkit of classroom activities. Newark, DE: The International Reading Association inc.

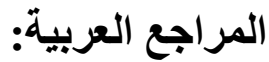

أمين، عمر (2006) : أثر استخدام أسلوبى التعلم بالاكتشـاف الموجـه و التعلم

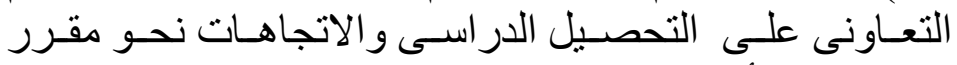

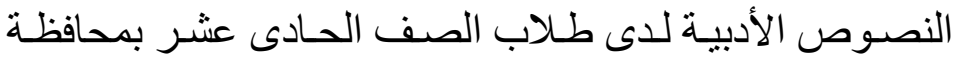

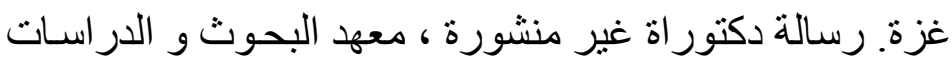
العربية ، جامعة الدول العربية ،القاهرة

الشندويلى، صبرى (2004) : أثز استخدام طريقة الاكتشاف الموجه فى تدريس

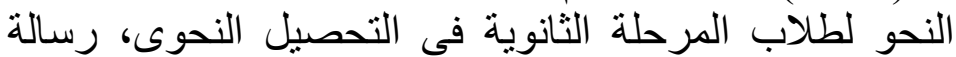

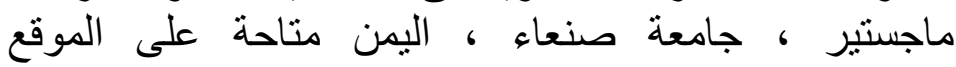
الالكثرونى ماجثر

http://kenanaonline.com/users/kadwany/posts/2 28738

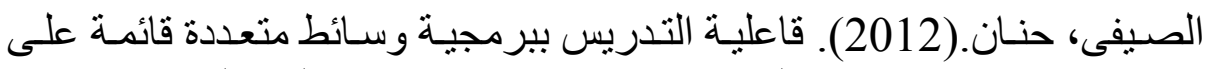

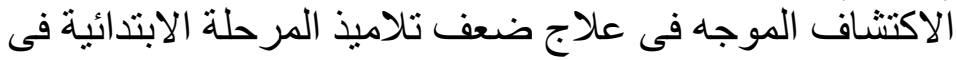

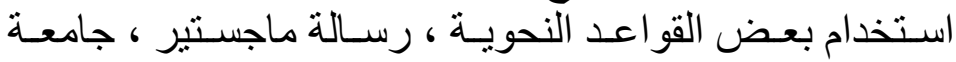

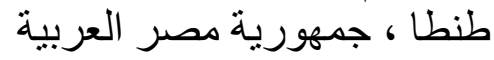

